Yüzüncü Yil Üniversitesi
Tarim Bilimleri Dergisi

Araştırma Makalesi (Research Article)

\title{
Kargı Kamışı (Arundo donax L.)'nda Tuz Stresinin Morfolojik ve Fizyolojik Özelliklere
} Etkisi

\author{
Alpaslan KUŞVURAN ${ }^{1 *}$, Şebnem KUŞVURAN ${ }^{1}$, Recep İrfan NAZLI ${ }^{2}$, Veyis TANSI ${ }^{2}$ \\ ${ }^{1}$ Çankırı Karatekin Üniversitesi, Kızılırmak Meslek Yüksekokulu, Kızılırmak, Çankırı, Türkiye \\ ${ }^{2}$ Çukurova Üniversitesi, Ziraat Fakültesi, Tarla Bitkileri Bölümü, Sarıçam, Adana, Türkiye \\ *Sorumlu yazar e-posta: kusvuran@karatekin.edu.tr; Tel: + 90 (376) 21811 23; Faks: + 90 (376) 3241018
}

\section{Makale Bilgileri}

Geliş: 19.12.2018

Kabul: 18.04.2019

Online Yayınlanma 28.06.2019

DOI: 10.29133/yyutbd.499322

\section{Anahtar Kelimeler}

Abiyotik stres,

Biyokütle,

Buğdaygil,

Enerji bitkileri,

Iyon
Öz: Tuzluluk, dünyada sulanabilir tarım alanlarının $\% 20$ 'den fazlasında görülen ve özellikle kurak-yarı kurak tarım alanlarını tehdit eden önemli bir abiyotik stres faktörüdür. Bu çalışmada, 0-kontrol, 50, 100, 150, 200 ve $250 \mathrm{mM} \mathrm{NaCl}$ tuz yoğunluklarının kargı kamışı (Arundo donax L.)'na etkileri incelenmiştir. Sulamaya öncelikle $50 \mathrm{mM}$ tuz konsantrasyonu ile başlanarak son doz olan 250 mM'a ulaşılmıştır. Kargı kamışının stres karşısında gösterdiği tepkiler bitkinin erken gelişim döneminde gözlemlenmiştir. Araştırmada, yaprak zararlanma indeksi, bitki yaş ve kuru ağırlı̆̆ı, kök yaş ve kuru ağırlığı, yaprak sayısı ve alanı, bitki boyu, sap kalınlığı, yaprak su potansiyel içeriği, klorofil değeri ile sodyum $(\mathrm{Na})$, potasyum $(\mathrm{K})$ ve kalsiyum $(\mathrm{Ca})$ içerikleri belirlenmiştir. Kargı kamışı farklı tuz konsantrasyonlarına karşı tolerans bakımından geniş bir varyasyon göstermiştir. Artan tuz konsantrasyonları ile birlikte bitkide morfolojik özellikler bakımından gerilemeler olmuş, bu etki özellikle $100 \mathrm{mM}$ tuz konsantrasyonu ile etkisini göstermiş ve en düşük değerler $250 \mathrm{mM}$ dozunda elde edilmiştir. En yüksek yaprak zararlanma indeksi (0-5 skalası) değerleri $250 \quad \mathrm{mM}$ konsantrasyonunda elde edilmiştir. Kontrol gruplarına göre yaprak yaş ve kuru ağırlıklarında sırasıyla $\% 27$ ve $\% 60$, kök yaş ve kuru ağırlıklarında ise $\% 13$ ve $\% 77$ oranında azalmalar tespit edilmiştir. Yaprak oransal su içeriği kontrol bitkilerinde $\% 85$ olarak saptanırken, bu değer $250 \mathrm{mM}$ konsantrasyonunda $\% 52.5$ olarak belirlenmiştir. Artan tuz stresine bağlı olarak klorofil içerikleri ile potasyum $(\mathrm{K})$ ve kalsiyum $(\mathrm{Ca})$ iyonlarında azalmalar görülürken, sodyum $(\mathrm{Na})$ iyonlarında ise artış meydana gelmiştir. Araştırmadan elde edilen sonuçlara göre, yüksek tuzluluk bitki büyüme ve gelişmesini olumsuz yönde etkilemiş, $150 \mathrm{mM}$ $\mathrm{NaCl}$ konsantrasyonunun bitki gelişimi üzerinde kritik doz olduğu sonucuna varılmıştır.

\section{Salinity Stress Effect on Morphological and Physiological Properties in Giant Reed (Arundo donax L.)}

\section{Article Info}

Recieved: 19.12 .2018

Accepted: 18.04.2019

Online Published 28.06.2019

DOI: 10.29133 /yyutbd.499322

Keywords

Abiotic stress,

Biomass,
Abstract: Salinity is a significant abiotic stress factor that threatens agriculture in both arid and semiarid environments, affecting over $20 \%$ of the world's irrigated land. In the present study, we have investigated that effects of different salinity levels (0, 50, 100, 150, 200, and $250 \mathrm{mM} \mathrm{NaCl})$ in giant reed (Arundo donax L.). Salt treatment was started as $50 \mathrm{mM}$ and this concentration was increased day after day, and finally $250 \mathrm{mM}$ concentration of $\mathrm{NaCl}$ was applied until harvest time. Stress responses of the giant reed were measured in early plant development stage. In conclusion, the giant reed showed large variation in their response to salt tolerance in different salt levels. The morphological parameters were reduced with increasing salt concentrations; important decreases occurred with $100 \mathrm{mM}$ 
Grasses, Energy plants, Ion
$\mathrm{NaCl}$ and the lowest values were obtained with $250 \mathrm{mM}$. The highest $0-5$ symptoms score were determined in $250 \mathrm{mM}$ levels. The fresh and dry weight, fresh and dry root weight decreased $27-60 \%$ and $13-77 \%$ compared to control groups, respectively. While the relative water content was obtained $85 \%$ in control plants, this parameter decreased $52.5 \%$ ration in $250 \mathrm{mM}$ salt level. The increasing salt stress caused decreasing in chlorophyll content. With increasing of salt levels, $\mathrm{Na}$ ion content increased on the other hand $\mathrm{K}$ and $\mathrm{Ca}$ ions contents diminished. The results obtained from this experiment show that high salinity reduced plant growth and development in giant reed. In these levels, $150 \mathrm{mM}$ $\mathrm{NaCl}$ concentration was determined at critical dose for plant development.

\section{Giriş}

Enerji bitkileri; çok farklı ekolojik koşullarda tarımı yapılabilen, toprak seçiciliği fazla olmayan türleri de bünyesinde bulunduran, fosil yakıtlar gibi çevreye zararı olmayan, aksine faydaları olan ve yenilenebilir kaynaklar olma özelliklerinden dolayı önemleri giderek artan bitkiler olup, enerji üretimindeki payları her geçen gün artmaktadır. Dünyada enerji bitkileri olarak en fazla değer gören çok yıllık serin mevsim buğdaygillerinden birisi de kargı kamıșı (Arundo donax L.)'dır. Bir $\mathrm{C}_{3}$ bitkisi olan kargı kamışı (Arundo donax L.), Akdeniz iklim koşullarında yaz sonuna doğru çiçeklenmekte ve yaz boyunca dormansiye girmeden büyümesini sürdürmektedir. Bitkinin ihtiyacı olan suyun karşılanması durumunda kargı kamışından yüksek biyokütle verimi elde edilmekte, bu özelliği nedeniyle de özellikle Yunanistan ve İtalya gibi Akdeniz ülkelerinde enerji bitkisi olarak fazlasıyla dikkat çekmektedir (Angelini ve ark., 2009). Ülkemizde Ege ve Akdeniz Bölgesi’nde, özellikle sahil kuşağında bataklık, dere, ırmak, göl vb. su kaynaklarının olduğu yerlerde doğal vejetasyonda yoğunlukla bulunmakla birlikte Çorum'un Kargı ilçesinde doğal olarak yayılış göstermektedir.

Tuz stresi toprakta ya da sulama suyunda, sınır değerlerin üzerinde bulunan farklı tuzların bitki büyümesini engellemesi ile ortaya çıkan bir abiyotik stres olup, karşımıza en çok sodyum klorür $(\mathrm{NaCl})$ formunda çıkmaktadır. Bitkiler, tuz stresi koşullarında, bitki gelişimini iki farklı şekilde engellemektedir. Bunlardan ilki olan osmotik etki; topraktaki tuz oranının artışına bağlı olarak artan ozmotik basınç ve su potansiyelinin düşmesi sonucu köklerin su alımının engellenmesi ile ortaya çıkan bir anlamda kuraklık stresi şeklinde tanımlanabilmektedir.

Diğer etki ise tuz iyonlarının yüksek konsantrasyonlarda olması halinde iyon dengesinin bozularak besin maddesi alımının engellenmesi şeklinde ortaya çıkan toksik etkidir (Stavridou ve ark., 2017). Tuza tolerans, yüksek değerlerde tuz konsantrasyonuna sahip olan ortamlarda bitkilerin büyüme ve gelişimini devam ettirebilme kabiliyeti şeklinde tanımlanmaktadır. Bitkiler bunu gerçekleștirmek için, tuzu kabullenme (inclusion) ve tuzdan sakınma (exclusion) mekanizmalarından birini devreye sokarak yüksek tuz içeriğine sahip ortamlarda büyüme ve gelişmelerini sürdürmektedirler (Kuşvuran, 2011). Bitkilerin tuza karşı toleransının belirlenmesinde önemli olan faktörlerden birisi de iyon regülasyonudur. Tuz koşulları altında bitki türleri dokularında düşük $\mathrm{Na}^{+}$ve $\mathrm{Cl}^{-}$alımı yanında daha yüksek oranlarda $\mathrm{K}^{+}$ve $\mathrm{Ca}^{++}$seviyelerinin oluşturulması toleransın anahtar mekanizmalarını oluşturmaktadır. Ayrıca, tuz stresine karşı yüksek tolerans gösteren bitkilerin dokularında K/Na oranı daha yüksektir (Daşgan ve Koç 2009; Acosta-Motos ve ark., 2017).

Bu çalışmada, dünya genelinde enerji bitkisi olarak önemi her geçen gün artan kargı kamışı (Arundo donax L.) türünün farklı tuz konsantrasyonları altında göstermiş oldukları tepkilerin incelenerek bitki büyüme gelişmesinde ortaya çıkan morfolojik ve fizyolojik etkilerin belirlenmesi amaçlanmıştır.

\section{Materyal ve Yöntem}

Araştırmada; Çankırı Karatekin Üniversitesi Kızılırmak Meslek Yüksekokulu Araştırma ve Uygulama Alanı'nda bulunan kargı kamışı (Arundo donax L.) bitkileri materyal olarak kullanılmıştır.

Çalışma, 2015 yılında, tesadüf parselleri deneme desenine göre, 4 tekrarlamalı olarak plastik serada gerçekleştirilmiştir. Kargı kamışı (Arundo donax L.) rizomları, 2 birim torf 1 birim perlit karışımı içeren 11 litre kapasiteli ve 57x16x12 cm ebatlarındaki plastik saksılara, her saksıda 6 adet 
rizom olacak şekilde, 29.07.2015 tarihinde dikilmiş ve rizomlar sürgün verdikten sonra sağliklı olan 3 tanesi bırakılmıştır.

Çalışmada, kontrol ile birlikte 6 farklı tuz konsantrasyonu (0-kontrol, 50, 100, 150, 200 ve 250 $\mathrm{mM}$ ) ele alınmıştır. Dikimden 10 gün sonra sürgün gelişimi gerçekleşmiş; 26 gün sonra, 24.08.2015 tarihinde, bitkiler iki gerçek yapraklı aşamaya ulaştıklarında tuz uygulamalarına geçilmiştir. $\mathrm{Bu}$ döneme kadar bitkiler Hoagland besin çözelti ile sulanmıştır (Daşgan ve Koç, 2009). Stres uygulamasına başlanmasından 32 gün sonra tuz zararının net olarak belirlenmesi ile birlikte bitkiler hasat edilerek morfolojik ve fizyolojik parametreler bakımından değerlendirilmiştir.

\section{1. İncelenen özellikler ve yöntemleri}

Skala (0-5) Değerlendirmesi: Bitkilerde morfolojik zararlanmanın derecesini belirlemek amacıyla Kuşvuran (2010) tarafından belirtilen şekilde 0-5 skalası esasına göre yapılmıştır.

Yaprak Saylsı (adet bitki ${ }^{-1}$ ) ve yaprak alanı $\left(\mathrm{cm}^{2}\right.$ bitki $\left.{ }^{1}\right)$ : Yaprakların sayılması suretiyle bitki başına yaprak sayısı adet olarak saptanmıştır. Yaprak alanı ise CI BIO Science CI 202 model yaprak alan ölçer aleti kullanılarak tespit edilmiştir.

Gövde Boyu $(\mathrm{cm})$ ve çapı $(\mathrm{mm})$ : Toprak yüzeyi ile en üst noktası arasındaki mesafe ölçülerek bitki boyu, sayısal kumpas kullanılarak alttan 2. ve 3. boğum arası ölçülerek bitki çapı belirlenmiştir.

Bitki Yaş ve Kuru A $\breve{g} ı$ rll $\breve{g} l ~\left(g\right.$ bitki $\left.{ }^{-1}\right)$ : Toprak üstünde kalan aksamın tamamı hassas terazide tartılarak ölçümleri yapılmıştır. Alınan bitki örnekleri $65^{\circ} \mathrm{C}$ 'de 48 saat süreyle etüvde kurutmaya tabi tutulmuş ve kuru ağırlıkları tespit edilmiştir.

Kök Yaş ve Kuru A $\breve{g}$ lrllı̆g $\left(g\right.$ bitki $\left.^{-1}\right)$ : Toprak altında kalan aksamın tamamı hassas terazide tartılarak ölçümleri yapılmıştır. Alınan kök örnekleri etüvde kurutularak bitki kuru ağırlıkları tespit edilmiştir.

Klorofil Spad Değeri: Minolta marka Spad Metre kullanılarak bitki yapraklarındaki klorofil miktarı belirlenmiştir.

Yaprak oransal su içeriği (YOSI): Aşağıda yer alan formül kullanılarak YOSİ değerleri (\%) hesaplanmıştır. (TA-KA) / (TuA-KA)x100 TA: Taze Ağırlık KA: Kuru Ağırlık TuA: Turgor Ağırlığı

Mineral Element Analizleri: Kurutulan örnekler öğütüldükten sonra $550^{\circ} \mathrm{C}$ 'de yakılarak kül elde edilmiş ve $\% 3.3(\mathrm{v} / \mathrm{v}) \mathrm{HCl}$ içerisinde çözündürüldükten sonra $\mathrm{Na}^{+}, \mathrm{K}^{+}$ve $\mathrm{Ca}^{++}$elementlerinin okumaları Atomik Absorsiyon Spektrometre cihazında emisyon modunda yapılmıştır (Daşgan ve Koç, 2009).

\subsection{Verilerin değerlendirilmesi}

Deneme verileri SAS 9.1 istatistik paket programında varyans analizine tabii tutulmuş ve uygulamalar arasındaki farkın önemli olduğu durumlarda $(\mathrm{P}<0.01)$ bu farklılık LSD çoklu karşılaştırma testi ile gruplandırılarak ortaya konulmuştur.

\section{Bulgular}

Farklı tuz konsantrasyonlarının kargı kamışında ortaya koyduğu değişimlerin incelendiği çalışmada, yeşil aksamda meydana gelen semptomolojik zararlanmanın etkisini tespit etmek için oluşturulan skala değerlendirmesinde kontrol bitkileri "0" olarak değerlendirilmiştir. Uygulanan farklı tuz konsantrasyonlarının bitkilerde farklı skala değerleri oluşturduğu tespit edilmiş, skala değerleri 1.0-4.0 arasında değişim göstermiştir. Çalışmada $50 \mathrm{mM}$ tuz konsantrasyonun bitkilerde 1.5 skala ile kontrol bitkilerine en yakın değeri aldıkları belirlenmiştir (Şekil 1.). Bununla birlikte en yüksek skala değeri 4.0 ile $250 \mathrm{mM} \mathrm{NaCl}$ uygulamasında saptanmıştır. Diğer uygulamalar arasında istatistiksel olarak bir fark bulunmamıştır. 


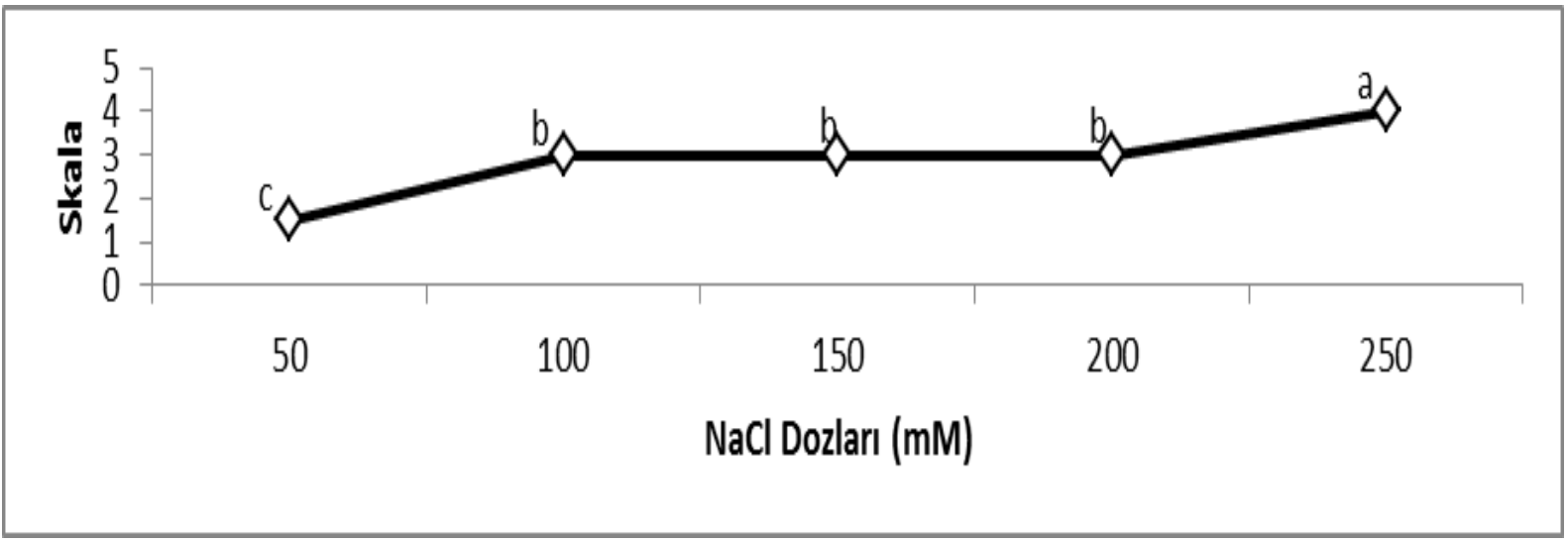

Şekil 1. Farklı tuz konsantrasyonlarının bitkilerde skala değerlendirmesi bakımından ortaya koydukları değişimler.

Farklı düzeylerdeki tuz stresi, bitkilerin yaş ve kuru ağırlıklarında değişen düzeylerde azalma şeklinde bir etkide bulunmuştur. Genel olarak bitki yaş ağırlıkları; 26.15-68.85 g bitki ${ }^{-1}$, kuru ağırlıkları ise 7.46-21.30 g bitki ${ }^{-1}$ arasında değişim göstermiştir (Şekil 2a. ve 2b.). Bitkiler kontrol bitkileri ile karşılaştırıldıklarında bitki yaş ve kuru ağırlıkları $50 \mathrm{mM}$ tuz konsantrasyonunda kontrol bitkilerine oranla sırasıyla $\% 2$ ve $\% 4$ oranında artış gösterirken; en yüksek değişim $250 \mathrm{mM} \mathrm{NaCl}$ uygulamasında \%61 ve \%64 oranında azalma şeklinde gerçekleşmiştir. Diğer tuz uygulamalarında ise ortaya çıkan değişim \%27-60 oranında belirlenmiştir.

Farklı tuz konsantrasyonlarının bitkilerin kök yaş ve kuru ağırlık değerlerine etkisinin istatistiki olarak önemli olduğu belirlenmiştir. Kök yaş ağırlığ 1 değerleri 14.80-51.86 g bitki ${ }^{-1}$, kuru ağırlıkları ise 1.37-6.18 $\mathrm{g} \mathrm{bitki}^{-1}$ arasında değişim göstermiştir (Şekil 2c. ve 2d.). Bitkiler kontrol bitkileri ile karşılaş̧ırıldıklarında kök yaş ve kuru ağırlıklarında ortalama \%52 ile \%58 arasında azalma meydana gelmiş, bu azalma en yüksek $250 \mathrm{mM} \mathrm{NaCl}(\% 71.5$ ve \%77.8) dozunda tespit edilmiştir.

Tuz stresine maruz bırakılan bitkilerde bitki boyu ve sap kalınlıklarında kontrol bitkilerine oranla azalma meydana gelmiştir. Artan stres düzeylerinde azalmanın belirginleştiği çalışmada bitki boyunda ortaya çıkan değişim \%10-41 (Şekil 3a.); sap kalınlığında ise \%3-33 (Şekil 3b.) oranlarında gerçekleşmiştir. Değiş̧imin en yüksek olduğu dolayısıyla kontrol bitkilerine oranla kayıpların en net olduğu $\mathrm{NaCl}$ dozu 200 ve $250 \mathrm{mM}$ olarak tespit edilmiştir.
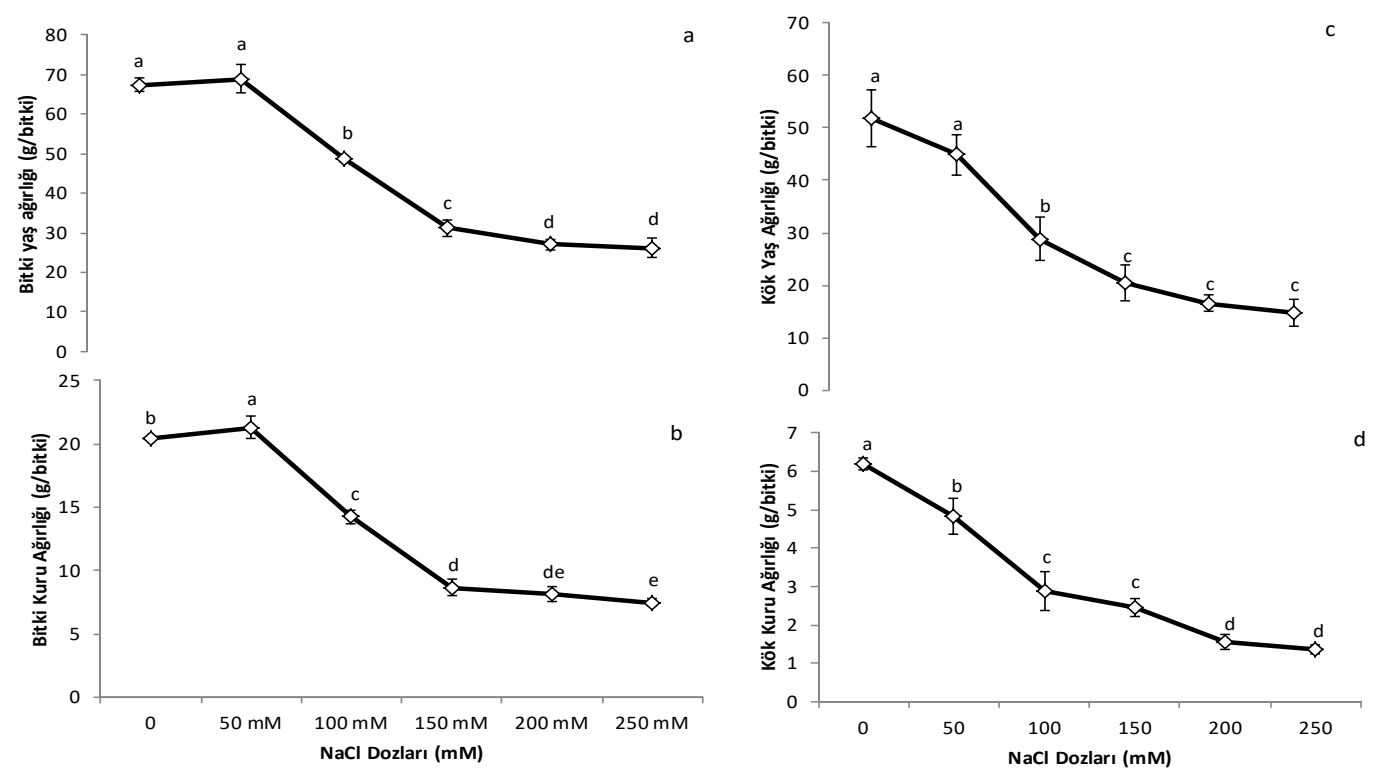
Şekil 2. Farklı tuz konsantrasyonlarının bitki yaş ağırlık (a), bitki kuru ağırlık (b), kök yaş ağırlık (c) ve kök kuru ağılık (d) üzerindeki etkisi.
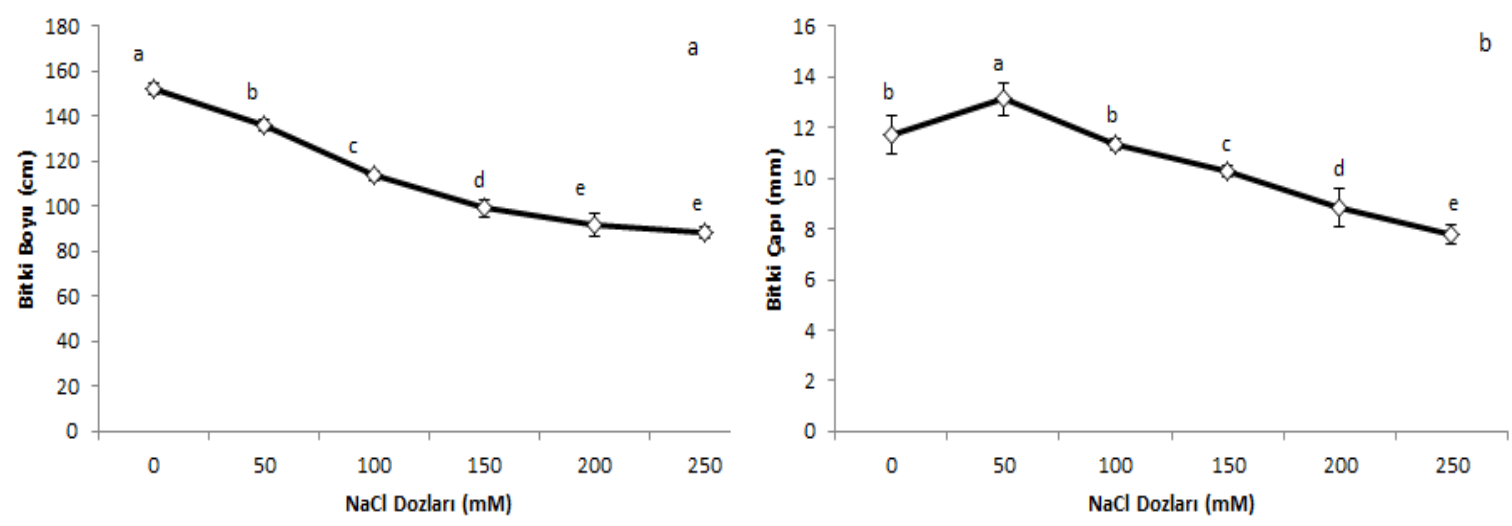

Şekil 3. Farklı tuz konsantrasyonlarının bitki boyu (a) ve gövde çapı (b) üzerindeki etkisi

Tuz stresinin etkisi, yaprak sayılarında ve alanlarında azalma şeklinde etkide bulunmuștur. Farklı tuz konsantrasyonlarının bitkide yaprak alanı ve sayısında meydana getirdiği etkilerin istatistiksel olarak da önemli bulunduğu çalışmada, yaprak sayısı kontrol bitkilerine kıyasla \%39 değişime neden olurken bu oran yaprak alanında ortalama olarak \%57 olarak bulunmuştur (Şekil 4a. ve 4b.). Her iki parametrede de en yüksek değişimler 200 ve $250 \mathrm{mM} \mathrm{NaCl}$ dozunda tespit edilmiştir. Buna göre farklı tuz dozlarında yaprak sayısında meydana gelen değişim \%45.1 ve \%50.7; yaprak alanı ise $\% 68.8$ ve $\% 78.8$ düzeyinde gerçekleşmiştir.
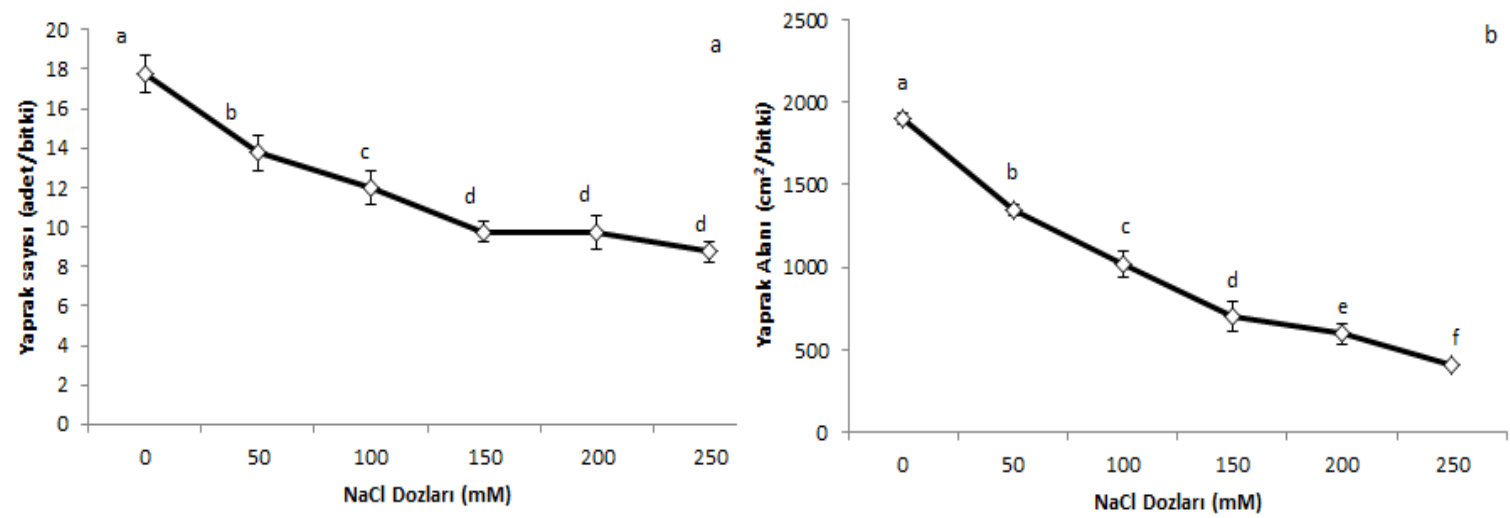

Şekil 4. Farklı tuz konsantrasyonlarının yaprak sayısı (a) ve yaprak alanı (b) üzerindeki etkisi

Farklı tuz konsantrasyonlarının spad değerlerinde de azalmaya neden olduğu saptanmıştır. Spad değerleri 32.43-43.50 arasında değişim göstermiştir (Şekil 5a.). Bununla birlikte $50 \mathrm{mM} \mathrm{NaCl}$ dozunda belirlenen Spad değerleri kontrol bitkileri ile karşılaştırıldıklarında \%1.21 düzeyinde azalma gösterirken; bu değerler $250 \mathrm{mM} \mathrm{NaCl}$ dozunda \%25.4 olarak belirlenmiştir.

Çalışmada yaprak oransal su içeriği (YOSI) değerleri kontrol bitkilerine oranla tuz stresi altındaki bitkilerde azalmalar göstermiş̧tir. Bitki YOSİ değerleri incelendiğinde; en yüksek YOSİ değeri \%85.74 ile kontrol bitkilerinde; en düşük oran ise $\% 52.54$ ile $250 \mathrm{mM} \mathrm{NaCl}$ uygulamasında belirlenmiştir (Şekil 5b.). 

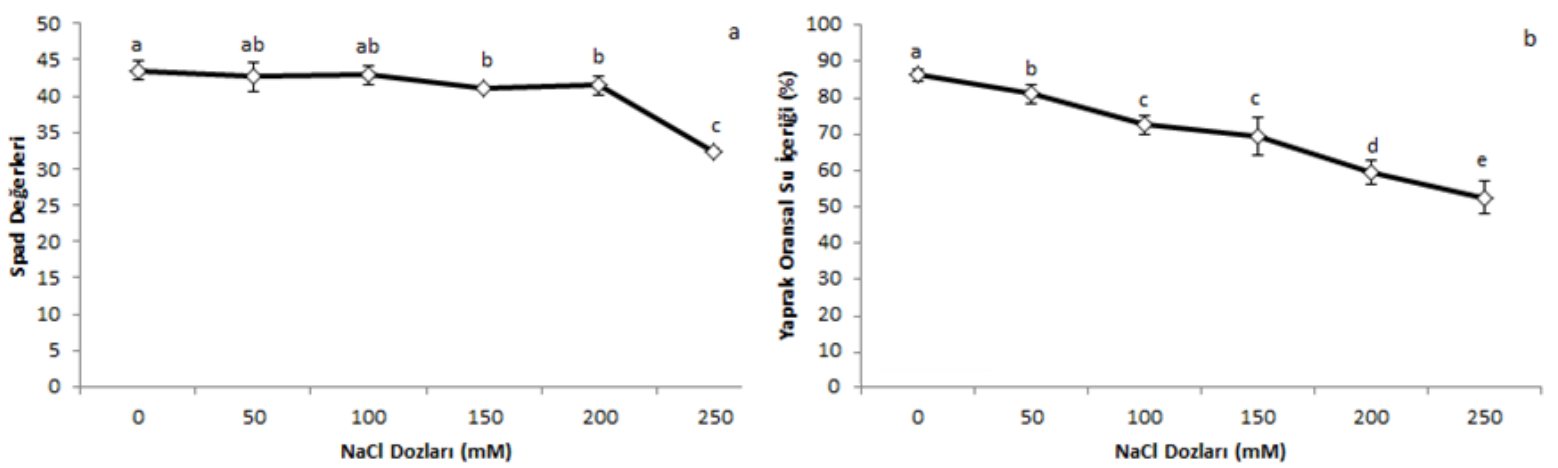

Şekil 5. Farklı tuz konsantrasyonlarının klorofil (spad) içeriği (a) ve yaprak oransal su içeriği (b) üzerindeki etkisi

Stres koşullarında iyon dengesi bakımından bitkilerin ortaya koydukları tepkiler farklılık göstermiştir. Tuz konsantrasyonlarının uygulanmasına bağlı olarak tüm $\mathrm{NaCl}$ uygulamalarında $\mathrm{Na}^{+}$ iyon oranları bitki yeşil aksamlarında yükselmiştir. Tuz uygulamaları ortalama olarak kontrol bitkilerine oranla \%216.3 oranında artış göstermiş; en yüksek artış \%342.7 ile $250 \mathrm{mM} \mathrm{NaCl}$ uygulamasında belirlenmiştir (Şekil 6a.). Potasyum ve kalsiyum iyon içeriklerinin de incelendiği çalışmada, tuz stresi bitkide her iki iyon bakımından da azalmaya neden olmuştur. Ortaya çıkan bu değişim tuz konsantrasyonu arttıkça etkili olmuş; $250 \mathrm{mM} \mathrm{NaCl}$ uygulamasında azalma $\mathrm{K}^{+}$için \%68.9; $\mathrm{Ca}^{++}$için ise \%84.8 olarak tespit edilmiştir (Şekil 6b. ve 6c.).

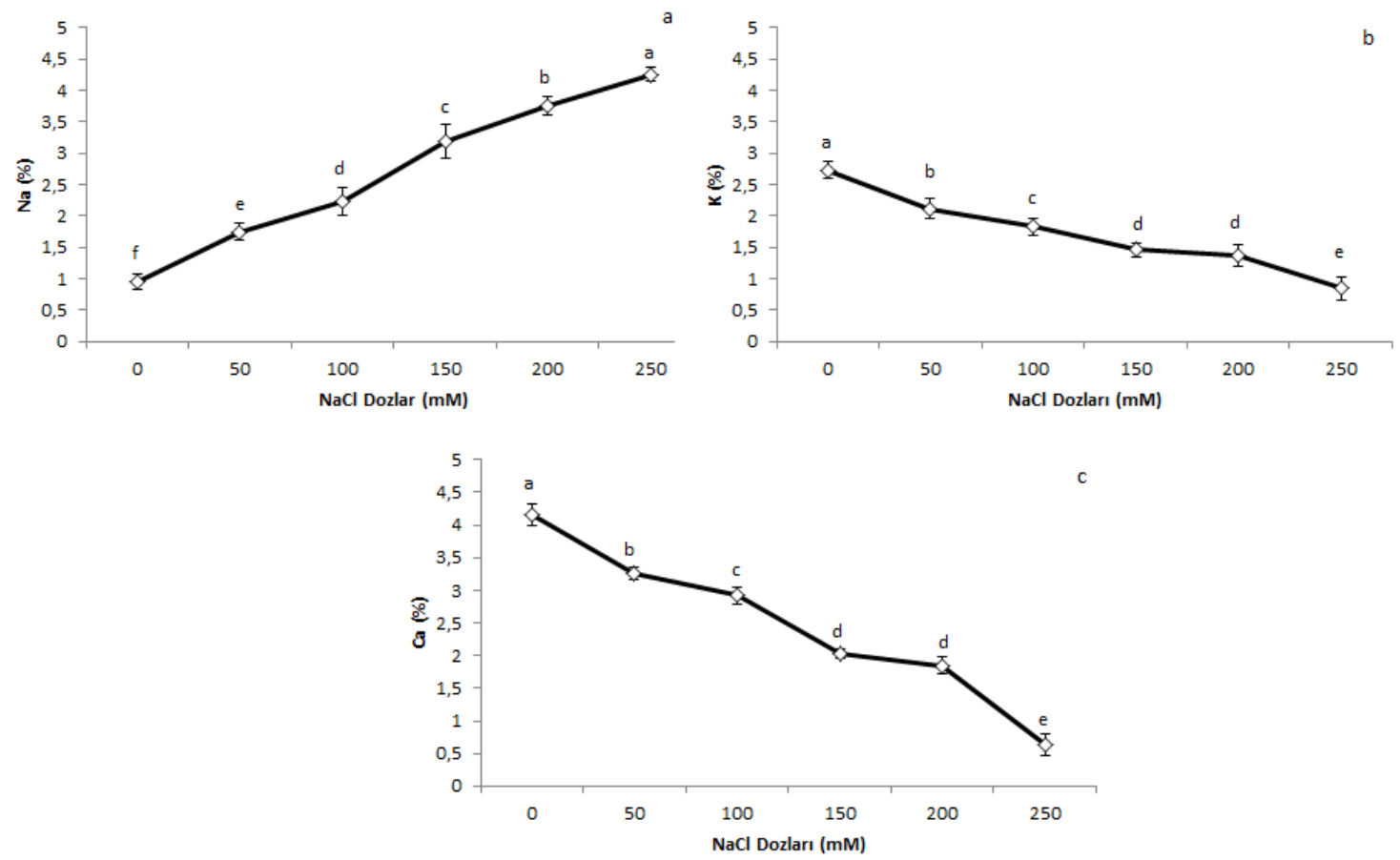

Şekil 6. Farklı tuz konsantrasyonlarının $\mathrm{Na}^{+}$(a), $\mathrm{K}^{+}$(b) ve $\mathrm{Ca}^{++}$iyon içerikleri üzerindeki etkisi

Bitkilerin tuz stresi koşullarında iyon seçiciliğinin belirlenebilmesi amacıyla $\mathrm{K} / \mathrm{Na}$ ve $\mathrm{Ca} / \mathrm{Na}$ oranları da incelenmiş; tuz stresindeki artışa bağlı olarak bitkilerde söz konusu oranlarda azalma meydana geldiği, dolayısıyla bünyelerine daha fazla Na iyonu aldıkları saptanmıştır (Şekil 7a. ve 7b.). 

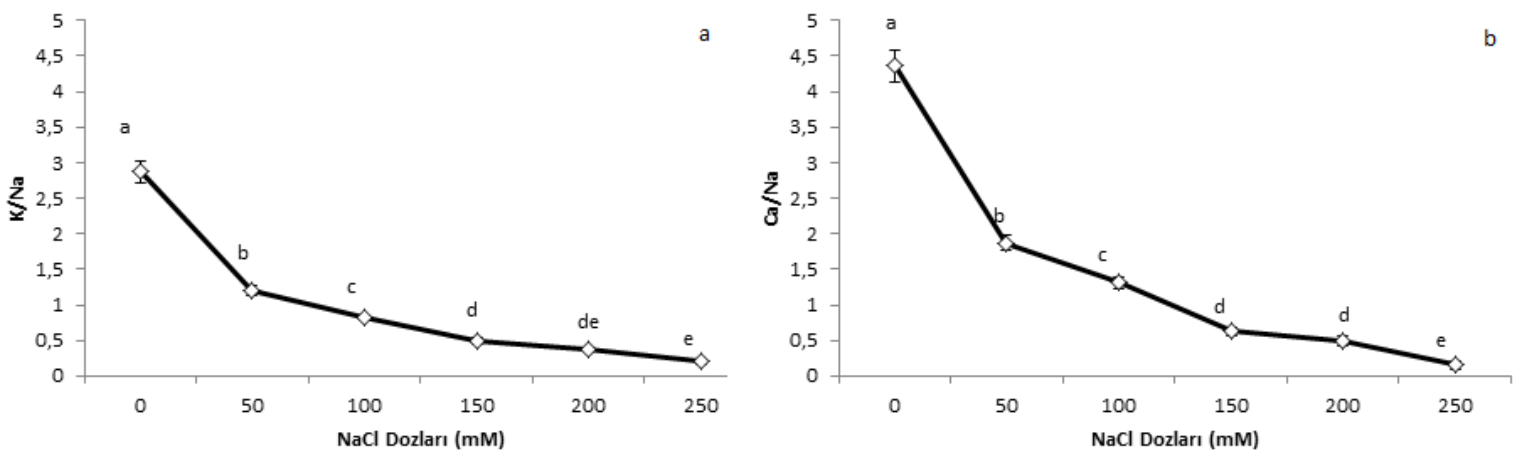

Şekil 7. Farklı tuz konsantrasyonlarının $\mathrm{K} / \mathrm{Na}$ (a) ve $\mathrm{Ca} / \mathrm{Na}$ oranları üzerindeki etkisi

\section{Tartışma ve Sonuç}

Bitkiler Na toksisitesine maruz kaldıkları zaman ilk önce yeşil aksamlarındaki büyümeyi yavaşlatma şeklinde bir tepki vermekte, bu süreci genellikle bitkinin yaşlı yapraklarından başlayan ve yaprak kınına doğru ilerleyen kloroz izlemektedir. Ortaya çıkan olumsuz etkilerin devam etmesi durumunda, klorozlar nekrozlara dönüşmekte ve ilerleyen aşamalarda yapraklarda kurumalar ortaya çıkmaktadır (Daşgan ve ark., 2017). Çalışmada artan tuz konsantrasyonlarına bağlı olarak bitki büyüme ve gelişmesinde azalma meydana gelirken; özellikle $250 \mathrm{mM} \mathrm{NaCl}$ dozu bitkilerde önemli zararlanmalar meydana getirmiştir.

Tuz stresi altında yetiştirilen bitkilerde, en önemli farklılıklar bitki yaş ve kuru ağırlıklarında meydana gelen azalma ile ortaya çıkmaktadır. Stres altındaki bitkilerde büyüme ve gelişmede görülen sınırlanmanın en önemli nedenlerinden biri stomaların kapanarak karbondioksit alımının azalması ve fotosentezin sınırlanmasıdır (Negrao ve ark., 2017). Bunun yanı sıra toksik iyon birikimine bağlı olarak ortaya çıkan iyon dengesizliği büyüme ve gelişmenin engellenmesine neden olmaktadır (Rady ve Mohammed, 2015). Kuşvuran ve ark., (2015) mısır, Stavridou ve ark., (2017) miskantus ve Pollastri ve ark., (2018) kargı kamışı bitkilerinde yaptıkları çalışmalarda tuz stresinin bitki gelişimi ve büyümesi üzerinde negatif etkiye neden olduğunu ifade etmişlerdir.

Primer kök sisteminin $\mathrm{NaCl}$ 'ye doğrudan maruz kalması nedeniyle, hücre genişlemesi ve hücre döngüsünün baskılanmasına bağlı olarak, kökün büyümesi doğrudan engellenmektedir (Doğu, 2017). Alzahrani-Motos ve ark., (2018) tuzluluk gibi abiotik stres faktörlerinin kök anotomisi üzerinde belirgin etkiler yaratabildiğini, kök gelişimini olumsuz etkileyebileceğini ifade etmişlerdir. Nitekim bu çalışmada, kök üzerinde belirgin etkilenme $150 \mathrm{mM} \mathrm{NaCl}$ dozundan itibaren net olarak ortaya çıkmıştır.

Tuz stresinin, bitki bünyesinde morfolojik ve fizyolojik olarak pek çok değişime neden olduğu birçok araştırıcı tarafindan bildirilmektedir (Negrao ve ark., 2017; Yang ve Guo, 2018). Bu değişimlerden birisi de tuz stresinin hücre bölünmesini ve uzamasını etkileyerek, bitkilerde kök ve gövdede hücre sayısının, mitotik aktivitenin ve hücre bölünme oranının azalmasına ve buna bağlı olarak bitki gelişiminde gerilemeye neden olmasıdır (Doğu, 2017). Mısır (Kuşvuran ve ark., (2015), miskantus (Stavridou ve ark., 2017) ve pamukta (Gao ve ark., 2018) gerçekleştirilen çalışmalar tuz stresinin bitki boyu ve gövde çapında azalmalara yol açtığını göstermiştir.

Tuz stresine bağlı olarak NaCl'nin yol açtığı toksisite ve su potansiyelinde meydana gelen azalma, bitki hücrelerinde ozmotik potansiyelin düşüş göstermesine ve bitki gelişiminde gerilemelere neden olmaktadır. Özellikle stomaların kapanması, bitkinin fotosentez hızının azalmasına ve ileriki dönemlerde ölümüne yol açmaktadır. Bu değişim süreci içerisinde tuz stresine en hassas olan bitki organları ise yapraklardır (Kuşvuran, 2011). Kuşvuran ve ark., (2015) mısır, Daşgan ve ark., (2017) domates ve Alzahrani ve ark., (2018) buğdayda gerçekleştirmiş oldukları çalışmalarında tuz stresi ile birlikte yaprak sayısı ve alanında azalma görüldüğünü bildirmişlerdir.

Tuz stresinin derecesinde görülen artışa bağlı olarak bitkilerde ölümler görülebilmekte, bitkinin tuza tolerant olması halinde ölümler olmasa dahi büyüme yavaşlamakta, kloroz ve nekrotik lekeler meydana gelmekte, bunlara bağlı olarak da verim ve kalitede düşüşler ortaya çıkmaktadır 
(Bayat ve ark., 2014). Yun ve ark., (2018) mısır bitkisinde yapmış oldukları çalışmalarında artan $\mathrm{NaCl}$ dozuna bağlı olarak klorofil içeriğinde azalma meydana geldiğini bildirmişlerdir. Nitekim çalışmamızda da benzer şekilde yüksek tuz konsantrasyonları iyon dengesizliği, toksik iyon etkisi ve stomaların kapanmasındaki düzensizlikler nedeniyle klorofil membranlarının zarar görerek Spad değerlerinde, dolayısıyla klorofil içeriğinde azalmalara neden olmuştur.

Tuz stresine maruz kalan bitkilerde su alımı engellenmekte, ozmotik etkiden dolayı bitkide büyüme ve gelişme yavaşlamakta, iyon toksisitesine bağlı olarak da yapraklarda suyun taşınmasını sağlayan hücrelerde zararlanmalar ortaya çıkmaktadır (Munns, 2005). Ghars ve ark., (2008) Arabidopsis thaliana ve Thellungiella halophila bitkilerinde artan $\mathrm{Na}$ iyonuna bağlı olarak bitki büyüme ve gelişiminde olumsuzluklar ortaya çıktığını ve YOSİ değerinin artışa bağlı olarak azalma şeklinde bir eğilim gösterebileceğini bildirmişlerdir.

Tuz stresinde zararlanma toprak çözeltisindeki yüksek tuz miktarına bağlı olarak osmotik basıncın artması ve toprak su potansiyelinin düşmesi ile sonuçlanan kuraklık stresi ile $\mathrm{Na}^{+}$ve $\mathrm{Cl}^{-}$gibi zararlı iyonların yüksek konsantrasyonu ve iyon konsantrasyonlarında dengesizlikler nedeniyle ortaya çıkmaktadır. Sodyum (Na) miktarında meydana gelen artış, genellikle ozmotik regülasyonu ve besin dengesini bozarak spesifik iyon toksisitesine girmekte, iyonik çaplarının ve elektriksel yüklerinin benzerliği nedeniyle $\mathrm{K}^{+}$iyonu ile rekabete girerek bu iyonun alımını da engellemektedir (Kuşvuran, 2011). Bitki hücresinde devam eden iyon taşınımı tek değerli $\left(\mathrm{K}^{+}, \mathrm{Na}^{+}\right)$ve çift değerli $\left(\mathrm{Ca}^{++}\right)$katyonlar arasındaki denge ile sürdürülmektedir. Tek değerli katyonların konsantrasyonunda meydana gelen artış, iyon taşınım dengesini değiştirerek hücre geçirgenliğinin bozulmasına ve hücrenin zararlanmasına neden olmaktadır (Yaşar ve ark., 2008). NaCl'nin bitkinin kalsiyum alımı ve taşınmasını azalttığı, kalsiyum yetersizliği ve bitkide iyon dengesizliğine neden olduğu bilinmektedir. Arpa, mısır, domates ve buğdayda gerçekleştirmiş oldukları çalışmalarda da tuz stresine maruz bırakılan bitkilerde toksik $\mathrm{Na}^{+}$iyon birikimi artış gösterirken; $\mathrm{K}^{+}$ve $\mathrm{Ca}^{++}$iyon alımının sınırlandığ birçok araştırıcı tarafından bildirilmiştir (Kuşvuran ve ark., 2015; Daşgan ve ark., 2017; Zhu ve ark., 2017; Yun ve ark., 2018; Alzahrani ve ark., 2018).

Farklı tuz konsantrasyonlarının kargı kamışı (Arondu donax L.) türünün morfolojik ve fizyolojik özelliklerine etkisinin belirlenmesi amacıyla yürütülen araştırmadan edilen sonuçlara göre; yüksek tuzluluğun bitki büyüme ve gelişimi üzerinde olumsuz yönde etkide bulunduğu, olumsuz etkinin $100 \mathrm{mM}$ ile kendisini göstermeye başladığg ve $150 \mathrm{mM} \mathrm{NaCl}$ konsantrasyonunun bitki gelişimi ve fizyolojisi üzerinde kritik konsantrasyon olduğu sonucuna varılmıştır.

\section{Kaynakça}

Acosta-Motos J. R., Ortuño M. F., Bernal-Vicente A., Diaz-Vivancos P., Sanchez-Blanco M. J., \& Hernandez, J. A. (2017). Plant responses to salt stress: adaptive mechanisms. Agronomy, 7(1), 18, 1-38.

Alzahrani, Y., Kusvuran, A., Alharby, H. F., Kusvuran, S., \& Rady, M. M. (2018). The defensive role of silicon in wheat against stress conditions induced by drought, salinity or cadmium. Ecotoxicology and Environmental Safety, 154, 187-196.

Angelini, L. G., Ceccarini, L., Nasso, N. N., \& Bonari, E. (2009). Comparison of Arundo donax L. and Miscanthus $x$ giganteus in a long-term field experiment in Central Italy: Analysis of productive characteristics and energy balance. Biomass Bioenergy, 33, 635-643.

Bayat, R. A., Kuşvuran, Ş., Ellialtıŏlu, Ş. Ş, \& Üstün, A. S. (2014). Tuz stresi altındaki genç kabak (Cucurbita pepo L. ve C. moschata Poir.) bitkilerine uygulanan prolin'in, antioksidatif enzim aktiviteleri üzerine etkisi. Türk Tarım ve Doğa Bilimleri Dergisi, 1, 25-33.

Daşgan, H. Y., \& Koç, S. (2009). Evaluation of Salt Tolerance in common bean genotypes by ion regulation and searching for screening parameters. Journal of Food, Agricyulture \& Environment, 7(2), 363-372.

Dasgan, H. Y., Bayram, M., Kusvuran, S., \& Coban Aydoner, G. (2017, December). Screening and saving of local tomatoes (Solanum lycopersicum) for their resistance to drought and salinity. Paper presented at the $92^{\text {nd }}$ International Conference, Russia.

Doğu, F. (2017). Allium cepa L.'nın bazı fizyolojik ve sitogenetik parametreleri üzerindeki tuz stresinin zararl etkilerinin hafifletilmesinde sodyum hipokloritin (NaClO) rolü. (Ms.C.), Selçuk Üniversitesi Fen Bilimleri Enstitüsü, Konya, Türkiye. 
Gao, W., Xu, F. C., Guo, D. D., Zhao, J. R., Liu, J., Guo, Y. W., \& Song, C. P. (2018). Calciumdependent protein kinases in cotton: insights into early plant responses to salt stress. BMC Plant Biology, 18, 1-15.

Goreta, S., Bucevic-Popovic, V., Vuletin Selak, G., Pavela-Vrancic, M., \& Perica, S. (2008). Vegetative growth, superoxide dismutase activity and ion concentration of salt-stressed watermelon as influenced by rootstock. The Journal of Agricultural Science, 146(6), 695-704.

Kuşvuran, Ş. (2011). Bamya (Abelmoschus esculentus L.) da tuz stresine tolerans bakımından genotipsel farklılıklar ve tarama parametrelerinin araştırılması. Batı Akdeniz Tarımsal Araştırma Enstitüsü Derim Dergisi, 28(2), 55-70.

Kusvuran, A., Uslu Kiran, S., Nazli, R. I., \& Kusvuran, S. (2015). Morphological response and ion regulation in maize (Zea mays L.) varieties under salt stress. Fresenius Environmental Bulletin, 24(1), 124-131.

Munns, R. (2005). Genes and salt tolerance: bringing them together. New Phytologist, 167, 645-663.

Negrao, S., Schmöckel, S. M., \& Tester, M. (2017). Evaluating physiological responses of plants to salinity stress. Annals of Botany, 119(1), 1-11.

Pollastri, S., Savvides, A., Pesando, M., Lumini, E., Volpe, M. G., Ozudogru, E. A., \& Fotopoulos, V. (2018). Impact of two arbuscular mycorrhizal fungi on Arundo donax L. response to salt stress. Planta, 247(3), 573-585.

Rady, M. M., \& Mohamed, G. F. (2015). Modulation of salt stress effects on the growth, physiochemical attributes and yields of Phaseolus vulgaris L. plants by the combined application of salicylic acid and Moringa oleifera leaf extract. Scientia Horticulturae, 193, 105-113.

Stavridou, E., Hastings, A., Webster, R. J., \& Robson, P. R. (2017). The impact of soil salinity on the yield, composition and physiology of the bioenergy grass Miscanthus $\times$ giganteus. GCB Bioenergy, 9(1), 92-104.

Yang, Y., \& Guo, Y. (2018). Elucidating the molecular mechanisms mediating plant salt-stress responses. New Phytologist, 217(2), 523-539.

Yasar, F., Ellialtioglu, S., \& Yildiz, K. (2008). Effect of salt stress on antioxidant defense systems, lipid peroxidation, and hlorophyll content in green bean. Russian. Journal of Plant Physiology, 55(6), 782-786.

Yun, P., Xu, L., Wang, S. S., Shabala, L., Shabala, S., \& Zhang, W. Y. (2018). Piriformospora indica improves salinity stress tolerance in Zea mays L. plants by regulating $\mathrm{Na}^{+}$and $\mathrm{K}^{+}$loading in root and allocating K+ in shoot. Plant Growth Regulation, 86, 323-331.

Zhu, M., Zhou, M., Shabala, L., \& Shabala, S. (2017). Physiological and molecular mechanisms mediating xylem $\mathrm{Na}+$ loading in barley in the context of salinity stress tolerance. Plant, Cell and Environment, 40(7), 1009-1020. 